\title{
Biological insights into the expression of translation initiation factors from recombinant CHOK1SV cell lines and their relationship to enhanced productivity
}

\author{
Emma J. Mead¹, Rosalyn J. Masterton*, Marc Feary†, Olga Obrezanova†, Lin Zhangł, Robert Young $†$ and C. Mark Smales ${ }^{\star 1}$ \\ ${ }^{*}$ Centre for Molecular Processing and School of Biosciences, University of Kent, Canterbury, Kent CT2 7NJ, U.K. \\ † Lonza Biologics plc, Portway Building, Granta Park, Great Abington, Cambridge CB21 6GS, U.K. \\ $\ddagger$ Pfizer Inc, 1 Burtt Road, Andover, MA 01810, U.S.A.
}

\begin{abstract}
Translation initiation is on the critical pathway for the production of monoclonal antibodies (mAbs) by mammalian cells. Formation of a closed loop structure comprised of mRNA, a number of eukaryotic initiation factors (eIFs) and ribosomal proteins has been proposed to aid re-initiation of translation and therefore increase global translational efficiency. We have determined mRNA and protein levels of the key components of the closed loop, eIFs (eIF3a, eIF3b, eIF3c, eIF3h, eIF3i and eIF4G1), poly(A)-binding protein (PABP) 1 and PABP-interacting protein 1 (PAIP1), across a panel of 30 recombinant mAb-producing GSCHOK1SV cell lines with a broad range of growth characteristics and production levels of a model recombinant mAb. We have used a multi-level statistical approach to investigate the relationship between key performance indicators (cell growth and recombinant antibody productivity) and the intracellular amounts of target translation initiation factor proteins and the mRNAs encoding them. We show that high-producing cell lines maintain amounts
\end{abstract}

of the translation initiation factors involved in the formation of the closed loop mRNA, maintaining these proteins at appropriate levels to deliver enhanced recombinant protein production. We then utilize knowledge of the amounts of these factors to build predictive models for and use cluster analysis to identify, highproducing cell lines. The present study therefore defines the translation initiation factor amounts that are associated with highly productive recombinant GS-CHOK1SV cell lines that may be targets for screening highly productive cell lines or to engineer new host cell lines with the potential for enhanced recombinant antibody productivity.

Key words: Chinese hamster ovary (CHO), monoclonal antibody, messenger ribonucleic acid (mRNA) translation initiation, predictive models, translation factors.

\section{INTRODUCTION}

Over the last 20-30 years significant increases in monoclonal antibody $(\mathrm{mAb})$ productivities from mammalian cell expression systems have been achieved by increasing the time integral of viable cell concentration (IVC) production rates $(\mathrm{qP})$ in the bioreactor via media development, feeding strategies and improved bioprocesses such that productivities in the range of 5$10 \mathrm{~g} / \mathrm{l}$ and beyond have now been reported [1]. The construction of mammalian cell lines for manufacture of $\mathrm{mAb}$ is a labourintensive process that relies heavily on selection strategies with multiple evaluation stages to identify high-producing cell lines early in the cell line construction process [2]. Screening strategies for the identification of good producing antibody cell lines tend to rely upon multiple screening throughout a cell line construction based upon productivity measurements, but these measurements do not always lead to the identification of the top performing cell lines when grown in the bioreactor [2,3]. Establishment of alternative selection criteria and/or markers that increase process predictability are therefore required to design enhanced selection strategies and to allow the identification of good producers at large scale as early as feasible in the cell line construction process (e.g. at the multi-well plate stage) [4].

An alternative to selecting high-producing variants during the cell line construction process is to pre-engineer cell lines for improved specific productivity or cell growth characteristics. For example, the development of vector systems with very efficient promoters and enhancers for transcription mean that high copy numbers of recombinant mRNAs can be achieved in recombinant cells lines [5,6]. However, consistently high levels of mRNAs encoding recombinant proteins have not resulted in a consistently improved $\mathrm{mAb}$ yield and systems biology modelling studies have identified limitations upon mRNA translation in high-producing cell lines $[5,7,8]$. As mRNA translation is on the critical pathway for recombinant protein production from cells [5,9] and is a tightly regulated process in this pathway, this is perhaps not surprising.

Within the process of translation, which is generally considered to consist of initiation, elongation, termination and recycling, initiation of mRNA translation is a key control point, directly influencing cell growth and protein synthesis [10] and requiring the co-ordination of numerous initiation factors, some of which are themselves comprised of multiple subunits. In addition to their specific roles in translation initiation, a number of the initiation factors have roles outside of the initiation complex and dysregulation of particular eukaryotic initiation factors (eIFs) has been shown to result in malignant transformation [10]. The largest scaffolding protein in the mammalian translation initiation complex is eIF3, which comprises 13 individual subunits [11]. The eIF3 scaffold interacts with the trimeric eIF4F complex

Abbreviations: 5'-TOP, 5'-terminal oligopyrimidine tract; elF, eukaryotic initiation factor; IVC, time integral of viable cell concentration; mAb, monoclonal antibody; PABP, poly(A)-binding protein; PAIP1, PABP-interacting protein 1; PCA, principal component analysis; PLS, partial least squares; qP, production rates; RMSE, root-mean-squared error.

1 Correspondence may be addressed to either of these authors (email e.j.hargreaves@kent.ac.uk or c.m.smales@kent.ac.uk). 
to control assembly of the $40 \mathrm{~S}$ ribosomal subunit on to $5^{\prime}$ capped mRNAs and therefore is essential in the rate-limiting assembly of the initiation complex during translation initiation [12]. Overexpression of five of the eIF3 subunits, eIF3a, $-3 b,-3 c$, $-3 \mathrm{~h}$ and $-3 \mathrm{i}$, has been shown to result in malignant transformation [13]. Cell lines overexpressing these subunits exhibit a number of oncogenic phenotypes that may be of advantage in cell lines intended for industrial production including, but not limited to, decreased doubling times, increased clonogenicity and viability, attenuated apoptosis, anchorage-independent growth and stimulation of initiation and global protein synthesis rates [13]. Furthermore, eukaryotic translation initiation factor eIF3i has a central role in directing cell growth and proliferation upon mild cold stress and subsequent recovery and in directing global mRNA translation [14]. Mild cold-stress is often used during fermentation for the production of recombinant biotherapeutic proteins produced from mammalian cells [15].

In its role as a scaffold protein, eIF3 is proposed to be central to circularization of mRNAs or the closed loop model of translation initiation [16,17]. The closed loop model proposes the interaction of the $5^{\prime}$ - and $3^{\prime}$-ends of the mRNA via a bridging mechanism mediated by a number of proteins, including several translation initiation factors [18]. It has been proposed and largely accepted that this circularization of mRNA enhances translation rates by enhanced recycling of ribosomes [19] and/or by ensuring eIF4F remains tethered to the mRNA and does not have to be re-recruited from the free eIF4F pool for every round of translation initiation [18]. The core bridge of the closed loop is formed between the 5'-cap, eIF4F (composed of eIF4A, eIF4E and eIF4G), eIF3, poly(A)-binding protein (PABP)-interacting protein 1 (PAIP1), PABP1 and the poly(A) tail.

In view of the importance of translation initiation in controlling protein synthesis and hence cell proliferation rates and recombinant protein synthesis, a number of approaches have been taken to manipulate specific translation initiation factors with the goal of increasing recombinant protein yield [20,21]. However, to date there has been no detailed study to identify if in an industrial cell line construction process amounts of the translation initiation factors correlate with key performance indicators such as the IVC and qP. In the present study, we report on the profiling of a panel of GS-CHOK1SV recombinant cell lines engineered to express a model $\mathrm{mAb}$ (previously generated and reported in [2]) for the amounts of key translation initiation factors and determine how these relate to $\mathrm{qP}$ and IVC. We show that all high-producing cell lines maintain the amounts of the translation initiation factors involved in the formation of the closed loop mRNA at appropriate levels to deliver enhanced recombinant protein production. The amounts of these factors can be used to build predictive models for high-producing cell lines, therefore defining the translation initiation factor amounts that are associated with highly productive recombinant GS-CHOK1SV cell lines.

\section{MATERIALS AND METHODS}

\section{Materials}

Materials were obtained from Sigma-Aldrich unless otherwise indicated below.

\section{Methods}

Generation of samples for Western blot (protein) and qRT (quantitative reverse transcriptase)-PCR (mRNA) analysis

From 175 cell lines constructed and progressed through all the assessment stages of a typical cell line construction strategy by
Lonza Biologics [2,3], a representative panel of 30 cell lines distributed across the productivity range of the founder panel were selected. Cells were grown in $\mathrm{CD}$ (chemically defined)- $\mathrm{CHO}$ (Chinese hamster ovary) medium (Invitrogen) supplemented with $25 \mu \mathrm{M}$ L-methionine sulfoximine under batch culture conditions in an orbital shaker at $140 \mathrm{rpm}, 36.5^{\circ} \mathrm{C}, 5 \%(\mathrm{v} / \mathrm{v}) \mathrm{CO}_{2}$. Cells were subjected to four routine passages prior to seeding $3 \times 100 \mathrm{ml}$ of cultures for each cell line in 500-ml Erlenmeyer flasks at $0.2 \times 10^{6}$ viable cells $/ \mathrm{ml}$. Cell counts were performed daily using a Vi-CELL 1.01 instrument (Beckman Coulter) to determine total and viable cell concentrations using the Trypan Blue dye exclusion method. Samples were taken at mid-exponential $(\sim$ day 4$)$ and stationary ( $\sim$ day 8$)$ growth phases for analysis. At each sampling point, $2 \times 10^{6}$ viable cells were collected by centrifugation at $3000 \mathrm{~g}$ for $3 \mathrm{~min}$, the supernatant removed and the remaining pellet lysed in buffer RLT (Qiagen RNeasy kit) and immediately stored at $-80^{\circ} \mathrm{C}$. Additionally, $1 \times 10^{7}$ viable cells were removed, centrifuged at $3000 \mathrm{~g}$ for $3 \mathrm{~min}$ at $4{ }^{\circ} \mathrm{C}$, the supernatant removed and the pellet lysed in $500 \mu \mathrm{l}$ of Western lysis buffer $[10 \mathrm{mM} \beta$-glycerophosphate, $20 \mathrm{mM}$ HEPES, $100 \mathrm{mM} \mathrm{NaCl}$ and $1 \%$ (w/v) Triton X-100 with $1 \mathrm{mM}$ $\mathrm{NaV}, 50 \mathrm{mM} \mathrm{NaF}$ and 1 protease inhibitor tablet (Roche complete mini EDTA-free 11836170001)] and immediately stored at $-80^{\circ} \mathrm{C}$. The cell culture was terminated and supernatant material harvested when average viability of triplicate cultures dropped below $50 \%$ viability. At this stage, $15 \mathrm{ml}$ of culture was removed, centrifuged at $3000 \mathrm{~g}$ for $3 \mathrm{~min}$ and the supernatant removed and stored at $-80^{\circ} \mathrm{C}$.

\section{ELISA and protein A HPLC}

Sandwich ELISAs were essentially performed as previously described [22] and absorbance read at $450 \mathrm{~nm}$ on a Multiskan Ascent plate reader V1.24. Standard curve analysis was performed in SigmaPlot version 11.0. Coefficient of variance was calculated $\left(\% C_{\mathrm{v}}=(\sigma / \mu) \times 100\right)$, using all values falling within the linear portion of the curve and any with a $\% C_{\mathrm{v}}>15 \%$ were rejected. Protein A HPLC was performed to a standard protocol [23].

\section{RNA preparation}

Cell lysates were thawed and a further $250 \mu \mathrm{l}$ of buffer RLT added. Samples were homogenized and RNA prepared using the commercially available Qiagen RNeasy kit following the animal spin cell protocol (with QIAshredder homogenization). The concentration of total RNA in the eluent was measured using a NanoDrop spectrophotometer (ND-1000) prior to storage at $-80^{\circ} \mathrm{C}$. Genomic DNA carry-over from RNA extraction was removed by treatment with RQ1 RNase free DNase (Promega).

\section{Primers for qRT-PCR mRNA analysis}

Primers were designed across an intron to regions of consensus sequence using Invitrogen OligoPerfect ${ }^{\mathrm{TM}}$ Designer (Supplementary Table S1).

\section{qRT-PCR}

qRT-PCR was carried out in a reaction volume of $20 \mu \mathrm{l}$ in low 96well white plates (BioRad) using the Qiagen Quantifast SYBR Green RT-PCR kit and gene specific primers (Supplementary Table S1) according to the manufacturer's instructions. qRT-PCR reactions were run on a BioRad DNA engine using the following programme: $50^{\circ} \mathrm{C} 10 \mathrm{~min}, 95^{\circ} \mathrm{C} 5 \mathrm{~min}, 40$ cycles of $95^{\circ} \mathrm{C} 10 \mathrm{~s}$, 
$58^{\circ} \mathrm{C} 30 \mathrm{~s}$, plate read and followed by a melting curve $58^{\circ} \mathrm{C}-$ $95^{\circ} \mathrm{C}$, read every $0.5^{\circ} \mathrm{C}$, hold $1 \mathrm{~s}$. Crossing point, comparative $\mathrm{Ct}$ and melting curve analysis were undertaken using the Opticon Monitor 3.1 software. $\beta 2 \mathrm{~m}$ and $\beta$-actin have previously been validated as housekeeping genes in $\mathrm{CHO}$ cells using microarray analysis [24] and were used for this purpose here. All samples were checked for the absence of DNA contaminants and inter- and intra-plate variance was assessed. Dual normalization to both housekeeping genes was carried out using a method adapted from the geNorm software (http://medgen. ugent.be/ jvdesomp/genorm/) [25].

\section{Western blot analysis of target proteins}

Lysed samples were thawed on ice and then sonicated (MSE Soniprep150 ultrasonic disintegrator, $16 \mu \mathrm{M}$ peak to peak, $3 \times 5 \mathrm{~s}$ ), centrifuged at $17000 \mathrm{~g}$ for $10 \mathrm{~min}$ at $4^{\circ} \mathrm{C}$ and the supernatant removed. The protein concentration was then determined by the method of Bradford [26]. SDS/PAGE analysis was performed using a standard protocol as described by Laemmli [27], with $20 \mu \mathrm{g}$ of total protein loaded/well on to either $8 \%$ or $10 \%$ acrylamide separation gels, as appropriate to the size of the target protein being probed. 'Dry-blotting' on to PVDF membrane was performed using the iBlot dry blotting system (Invitrogen). Wet blots (eIF4G1) were used only for transfer of eIF4G to nitrocellulose. Membranes were blocked in $5 \%(\mathrm{w} / \mathrm{v})$ Marvel in Tris-buffered saline. Primary antibodies were sourced as follows: Cell Signalling anti-eIF3a and anti-eIF4G1; Santa Cruz anti-eIF3b; Sigma anti-eIF3c, anti-eIF3h and anti- $\beta$-actin; ProteinTech group anti-eIF3i and anti-PAIP1. The anti-PABP1 antibody was a kind gift of the Dreyfuss laboratory [28]. Bound primary antibodies were detected by chemiluminescence using horseradish peroxidise-conjugated secondary antibodies (Dako swine anti-rabbit, Dako rabbit anti-mouse, Santa Cruz rabbit anti-goat) as appropriate and Hyperfilm ECL (GE Healthcare). Linearity of the response was established and blots within the dynamic range of the film were scanned and densitometry performed using the Aida Image Analyser version 4.15. Samples on each gel were internally normalized to a control sample and $\beta$-actin blots were used to normalize for protein loading.

\section{Statistical analysis of data}

Data were initially assessed individually by linear regression using the Minitab 16 statistical software. Correlation of IVC, specific production rate and final product titre with the amount of protein and mRNA of each initiation factor were investigated with a significance value of $P \leqslant 0.05$. Due to the stoichiometric nature of the eIFs in the initiation complex, some co-linearity is expected within the responses; additionally, there are a high number of descriptors for the number of observations and therefore a model building approach using simple linear regression is not appropriate. For this reason, a partial least squares (PLS) model was applied [29]. Such a model reduces predictors to a set of uncorrelated components and then performs least squares regression on the components. This is a multivariate model and hence the responses observed can vary from those observed when applying an individual regression analysis [30]. Matlab Statistics Toolbox built-in function plsregress was used for PLS analysis. The analysis was performed on mean-centred and unitvariance scaled data. The optimal number of PLS components was determined by manually minimizing the RMSE (root-meansquared error) obtained by cross-validation (five groups) with 30 Monte-Carlo repetitions. The final model for $\mathrm{qP}$ and day 8
mRNA data was built on the whole data set (30 cell lines) and used four PLS components. PLS analysis allows the direct relation of predictive variables to target variables and was the model of choice. Where PLS modelling was not successful, principal component analysis (PCA) analysis was used. PCA analysis was performed on data without scaling to unit variance. Matlab Statistics Toolbox built-in function $p c a$ was used to perform the analysis. Correlation analysis was performed using Matlab Statistics Toolbox built-in function corr and Pearson's linear correlation coefficient used to examine correlations. Cell lines were clustered using Matlab Statistics Toolbox built-in function clusterdata to perform hierarchical clustering and a maximum cluster value of 7 investigated for all data sets. Analysis of mRNA data was performed using Matlab version R2010b, whereas analysis of protein data was performed using Matlab version R2013a.

\section{RESULTS}

\section{Data sampling}

To determine if there was any correlation of product titre and IVC with translation initiation factor levels, cell lines were ranked according to harvest-product concentration [ranging from 22 to $691 \mathrm{mg} / \mathrm{l}$ (Table 1)], so that subsequently measured amounts of translational factors could be compared with product quantity and IVC. In order to minimize volume reduction within the culture to $<10 \%$ during sampling throughout the batch culture, it was not possible to take supernatant samples every day and therefore a true value of $\mathrm{qP}$ [3] could not be estimated. However, qP was estimated from final product concentration and IVC values. As expected, some minor differences in absolute concentration and ranking position were noted between the present study and the initial study when these cell lines were generated (result not shown) and therefore comparisons at the batch culture scale are only drawn from data generated during the current study. Cell samples were taken in order to determine amount of eIF mRNA and proteins on day 4 (exponential) and day 8 (start of decline) of batch culture (Figure 1A).

\section{qRT-PCR analysis of target translation initiation factor mRNA amounts}

The relationship between mRNA expression levels of each target gene, growth and productivity of each cell line was investigated by relative qRT-PCR analysis (Figure 2). In undertaking this analysis we needed to consider that some eIFs have been suggested to have roles outside of their direct role in translation initiation. In many cases, these additional functions are not clearly defined and would potentially result in a translation independent effect on the response variables, therefore data were initially assessed using linear regression (Table 2; Supplementary Figure S1). Global translation is usually maximal during exponential growth phase (equivalent to day 4 samples) when the requirement for accumulation of cellular proteins is at its highest [31]. Given that the requirement for eIFs in the process of translation initiation is stoichiometric, a limitation upon any one of the levels of these factors during exponential growth may result in a global attenuation of translation initiation and potentially limit growth rate, IVC and/or specific production rate. During the decline phase (day 8 samples), cells experience higher levels of stress from their environment and the extra synthetic burden of $\mathrm{mAb}$ production and ultimately this may result in the attenuation of translation via stress response pathways [32]. The ability of a cell 
Table 1 Growth and productivity data of the 30 recombinant $\mathrm{CHO}$ cell lines in batch culture investigated in the present study

All data presented as mean \pm S.D. Estimated specific production rate $=$ product concentration/IVC

\begin{tabular}{llcl}
\hline Cell line & Product concentration $(\mathrm{mg} / \mathrm{l}) \pm$ S.D. & IVC $\left(10^{6}\right.$ cells/ml.h $) \pm$ S.D. & Estimated specific production rate $(\mathrm{pg} / \mathrm{m} / \mathrm{h}) \pm$ S.D. \\
\hline 71 & $691 \pm 0$ & $1204 \pm 55$ & $0.572 \pm 0.062$ \\
75 & $609 \pm 3$ & $1162 \pm 24$ & $0.532 \pm 0.016$ \\
149 & $563 \pm 2$ & $1332 \pm 31$ & $0.413 \pm 0.001$ \\
137 & $541 \pm 0$ & $1174 \pm 73$ & $0.491 \pm 0.014$ \\
46 & $491 \pm 12$ & $1226 \pm 50$ & $0.405 \pm 0.054$ \\
124 & $427 \pm 1$ & $904 \pm 18$ & $0.465 \pm 0.013$ \\
42 & $417 \pm 45$ & $1322 \pm 28$ & $0.312 \pm 0.058$ \\
56 & $415 \pm 8$ & $1395 \pm 115$ & $0.324 \pm 0.001$ \\
38 & $406 \pm 6$ & $1027 \pm 41$ & $0.380 \pm 0.000$ \\
106 & $400 \pm 47$ & $1253 \pm 52$ & $0.333 \pm 0.071$ \\
76 & $395 \pm 4$ & $936 \pm 25$ & $0.411 \pm 0.004$ \\
150 & $392 \pm 19$ & $1303 \pm 22$ & $0.301 \pm 0.033$ \\
48 & $372 \pm 18$ & $1123 \pm 75$ & $0.312 \pm 0.005$ \\
77 & $357 \pm 15$ & $1182 \pm 52$ & $0.292 \pm 0.034$ \\
121 & $350 \pm 5$ & $1165 \pm 34$ & $0.308 \pm 0.011$ \\
40 & $346 \pm 87$ & $1387 \pm 114$ & $0.247+0.039$ \\
34 & $337 \pm 10$ & $1509 \pm 36$ & $0.218 \pm 0.006$ \\
35 & $325 \pm 4$ & $1505 \pm 53$ & $0.215 \pm 0.015$ \\
164 & $306 \pm 21$ & $1006 \pm 19$ & $0.304 \pm 0.016$ \\
2 & $298 \pm 25$ & $1411 \pm 12$ & $0.211 \pm 0.021$ \\
97 & $272 \pm 37$ & $1345 \pm 46$ & $0.197 \pm 0.046$ \\
114 & $244 \pm 45$ & $723 \pm 14$ & $0.342 \pm 0.083$ \\
25 & $240 \pm 68$ & $1254 \pm 42$ & $0.191 \pm 0.088$ \\
41 & $200 \pm 49$ & $1094 \pm 199$ & $0.155 \pm 0.053$ \\
24 & $171 \pm 15$ & $1107 \pm 26$ & $0.158 \pm 0.014$ \\
142 & $162 \pm 56$ & $1287 \pm 56$ & $0.120 \pm 0.055$ \\
146 & $146 \pm 0$ & $1271 \pm 71$ & $0.109 \pm 0.003$ \\
127 & $138 \pm 5$ & $708 \pm 27$ & $0.200 \pm 0.005$ \\
33 & $74 \pm 4$ & $1385 \pm 61$ & $0.051 \pm 0.001$ \\
52 & $22 \pm 8$ & $686 \pm 8$ & $0.032 \pm 0.017$ \\
& & & \\
\hline 5 & & &
\end{tabular}

A

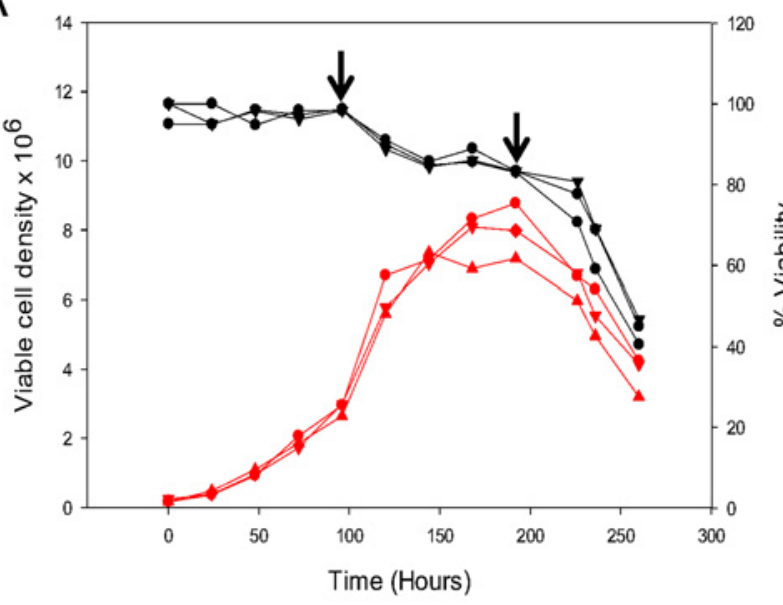

B

\begin{tabular}{|c|c|c|}
\hline Tar: & $\begin{array}{c}\text { Target Protein } \\
14614915016435 c \text { (Cell line) }\end{array}$ & $\begin{array}{c}\boldsymbol{\beta} \text { - actin } \\
14614915016435 c \text { (Cell line) }\end{array}$ \\
\hline elF3a & $-m-\infty=\begin{array}{l}-250 \mathrm{kDa} \\
-150\end{array}$ & $\begin{array}{c}-50 \mathrm{kDa} \\
-37\end{array}$ \\
\hline elF3 & $-\infty-\infty \begin{array}{l}-150 \\
-100\end{array}$ & 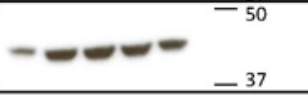 \\
\hline & 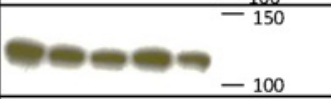 & $=\omega=0=0 \begin{array}{l}-50 \\
-37\end{array}$ \\
\hline el & -37 & 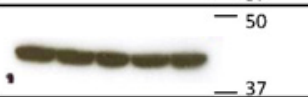 \\
\hline elF3i & ------37 & $\begin{array}{r}=50 \\
-m=-37 \\
-37\end{array}$ \\
\hline elF4 & $=\begin{array}{l}-250 \\
-150\end{array}$ & $\begin{array}{r}-50 \\
-37 \\
-3\end{array}$ \\
\hline PABP1 & $\sim---75$ & -37 \\
\hline PAIP1 & -----50 & $\begin{array}{r}-50 \\
-37\end{array}$ \\
\hline
\end{tabular}

Figure 1 Data sampling and antibody validation

(A) Representative growth (red data points) and viability (black data points) curves, performed in triplicate for each cell line in the member panel. Arrows denote sampling points at mid-exponential and stationary growth phases (day 4 and day 8 of culture respectively). (B) Western blots were optimized for each of the target proteins alongside control blots for the housekeeping gene $\beta$-actin. 

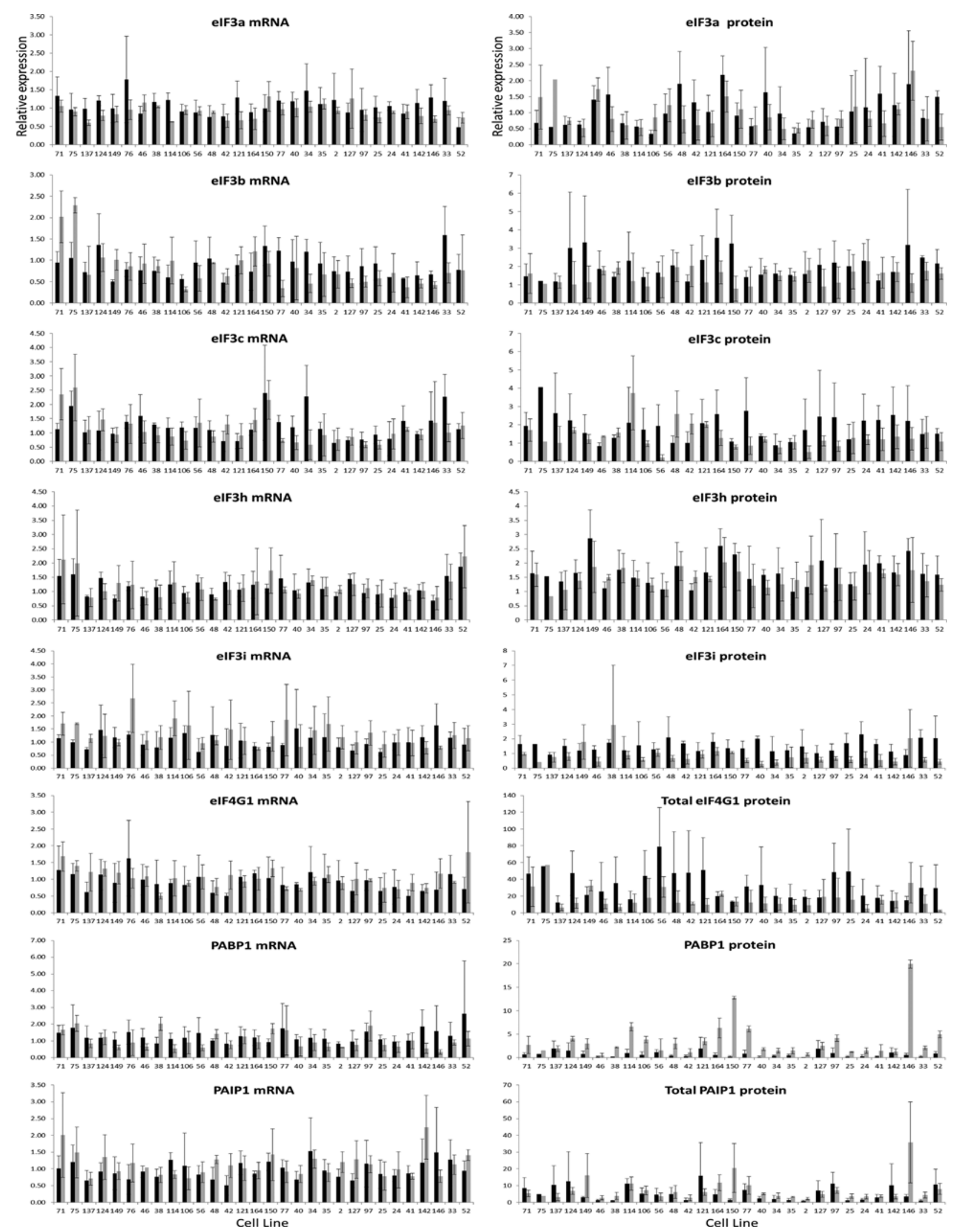

Figure 2 Relative expression of target mRNAs/proteins on day 4/day 8 of culture

Expression data for each of the target mRNAs/proteins across the cell line panel. mRNA data are expressed relative to the geometric mean of independent housekeeping genes and protein data are expressed relative to the housekeeping gene $\beta$-actin on day 4 (black) and day 8 (grey) of culture. Cell lines ranked according to estimated specific production rate [high (left) to low (right)]. Data are expressed as mean \pm S.D. 
Table 2 Linear regression analysis of target gene mRNA/protein expression levels on day $\mathbf{4}$ and day 8 of culture

Those targets with a statistically significant correlation $(P \leqslant 0.05)$ with each of the desirable cell line characteristics are listed alongside their significance value.

\begin{tabular}{|c|c|c|c|c|c|c|c|c|}
\hline \multicolumn{2}{|c|}{ Individual linear regression } & \multicolumn{4}{|c|}{ Day $4(P<0.05)$} & \multicolumn{3}{|c|}{ Day $8(P<0.05)$} \\
\hline \multirow[t]{2}{*}{ mRNA } & $\begin{array}{l}\text { Target compared with } \\
\text { batch culture IVC }\end{array}$ & & & elF3h & $\left(R^{2}=0.141\right)$ & & & \\
\hline & $\begin{array}{l}\text { Target compared with } \\
\text { batch culture final titre }\end{array}$ & & & & & $\begin{array}{l}\text { elF3b } \\
\text { elF3c } \\
\text { PABP1 }\end{array}$ & $\begin{array}{l}\left(R^{2}=0.358\right) \\
\left(R^{2}=0.209\right) \\
\left(R^{2}=0.149\right)\end{array}$ & \\
\hline \multirow[t]{2}{*}{ Protein } & $\begin{array}{l}\text { Target compared with } \\
\text { batch culture IVC }\end{array}$ & & & $\begin{array}{l}\text { elF4G1 C } \\
\text { PABP1 } \\
\text { PAIP1S } \\
\text { PAIP1 L } \\
\text { PAIP1 T } \\
\end{array}$ & $\begin{array}{l}\left(R^{2}=0.165\right) \\
\left(R^{2}=0.166\right) \\
(R=0.245) \\
\left(R^{2}=0.141\right) \\
\left(R^{2}=0.231\right)\end{array}$ & & & $\left(R^{2}=0.205\right)$ \\
\hline & $\begin{array}{l}\text { Target compared with } \\
\text { batch culture specific } \\
\text { production rate }\end{array}$ & $\begin{array}{l}\text { elF4G1 L } \\
\text { PAIP1L }\end{array}$ & $\begin{array}{l}\left(R^{2}=0.144\right) \\
\left(R^{2}=0.146\right)\end{array}$ & & & $\begin{array}{l}\text { elF4G1 S } \\
\text { elF4G1 L } \\
\text { elF4G1T } \\
\text { PABP1 }\end{array}$ & $\begin{array}{l}\left(R^{2}=0.188\right) \\
\left(R^{2}=0.223\right) \\
\left(R^{2}=0.143\right) \\
\left(R^{2}=0.188\right)\end{array}$ & \\
\hline
\end{tabular}

line to respond in a controlled manner to such demands and stress will determine how long into the decline phase global protein synthesis and mAb production is sustained. On day 4 of the culture, a negative association with the amount eIF3h mRNA and IVC and a positive association of the amount of eIF4G with specific production rate were found by linear regression. On day 8 , there were positive associations with product yield, the strongest relationship being between eIF3b mRNA and product concentration in harvest medium (Supplementary Figure S1).

Although informative for the purpose of assessing contributions of the individual targets to desirable cell productivity and growth characteristics, individual linear regression does not consider the stoichiometric nature of the eIFs in the initiation complex. For this reason, the data were modelled using the PLS method (Figures $3 \mathrm{~A}$ and $3 \mathrm{~B}$ ). On day 8 , only specific production rate data resulted in a model of satisfactory quality. The model has a coefficient of determination $R^{2}=0.74$ estimated on the whole set and $R^{2}{ }_{\mathrm{CV}}=$ 0.45 obtained by cross-validation. None of the initiation factors have a correlation coefficient of $>0.9$ with each other and all of them were included in the model. The model has the following form:

estimated specific production rate $=\beta_{0}+\beta_{1} x_{1}+\beta_{2} x_{2}$

$$
+\ldots+\beta_{8} x_{8}
$$

where $\beta_{\mathrm{i}}[i=0,1$ (eIF3a), 2 (eIF3b), 3 (eIF3c), 4 (eIF3h), 5 (eIF3i), 6 (eIF4G1), 7 (PABP1), 8 (PAIP1) are coefficients $\left(\beta_{0}=\right.$ $-0.0170, \beta_{1}=0.0938, \beta_{2}=0.2317, \beta_{3}=0.0284, \beta_{4}=-0.2630$, $\beta_{5}=0.1212, \beta_{6}=0.1339, \beta_{7}=0.0206$ and $\left.\left.\beta_{8}=-0.000065\right)\right]$ and $x_{\mathrm{i}}$ is the qRT-PCR value for $i$ th target gene.

Scaled coefficients (Figure 3A) illustrate the importance of each variable in describing the modelled property; the most important descriptors have scaled coefficients with larger absolute values. In this model, the most important descriptor having a negative influence on specific production rate is eIF3h. The most important descriptors having a positive influence on specific production rate are eIF3b $>$ eIF3i $>$ eIF4G1. The multi-variate nature of this model means that responses can often vary from individual analysis; however, in each case, the target mRNA having the largest negative relationship with desirable parameters was identified as eIF3h and the mRNA having the largest positive relationship was identified as eIF3b. No successful model could be generated using PLS for analysis of the day 4 data. Constructed models achieved $R^{2}$ values ranging between 0.2 and 0.5 with a much lower $R^{2}{ }_{\mathrm{CV}}$ and, as a result, correlation between predicted and observed property values was not statistically significant.

PLS data modelling identifies parameters with the best power to predict the modelled property; an alternative multivariate approach to data analysis is PCA, which identifies a new set of variables that best explain the variability in the data set (Figures 3C, 3D, 3G and 3H). PCA models were successfully generated for both day 4 and day 8 data sets. On day 4 , four components explain $86 \%$ of the variance of the data, with the first principal component explaining $41 \%$ of the data variance and the target gene mRNA level that has the highest positive contribution to that component is eIF3c. On day 8 , three components explain $81 \%$ of the variance in the data, with the first component describing $53 \%$ of the variance and with eIF3b and eIF3c contributing the most to this component.

The second question to be addressed by these data was whether the amount of any of the target mRNAs is correlated with any of the others (Figures $3 \mathrm{E}$ and $3 \mathrm{~F}$ ). On both day 4 and day 8 , the highest correlation between factors was between the mRNAs encoding the functional core subunits of eIF3: eIF3b and eIF3c. This result was not unexpected given that MS data have previously shown that these two subunits form a key interaction between stable modules of eIF3 [33,34].

The final question asked of the individual mRNA data sets was whether the cell lines themselves cluster in terms of 

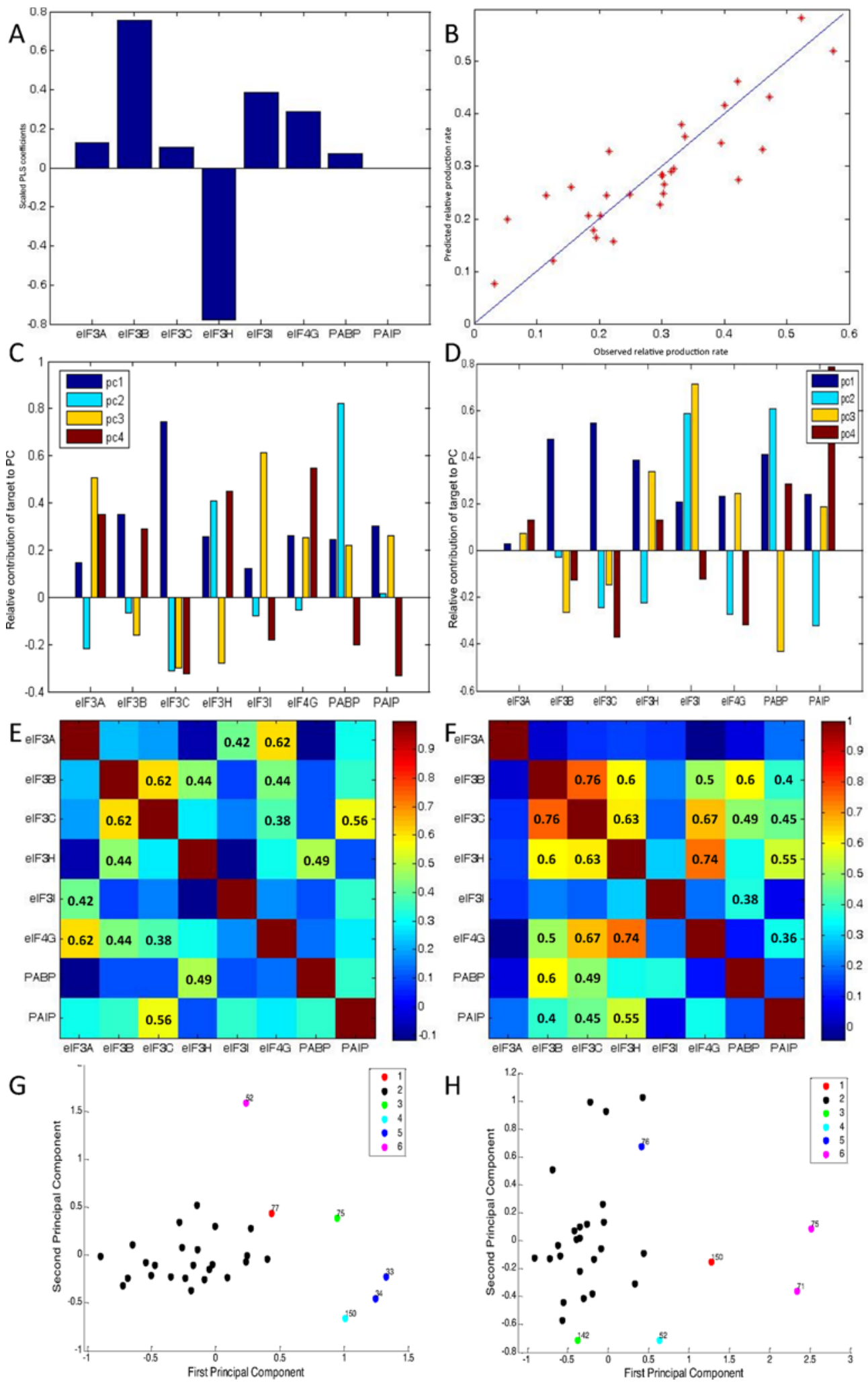

\section{Figure 3 PLS, principal component and cluster analysis of target gene mRNA data}

(A) Bar chart of scaled PLS coefficients for mRNA levels of eight target genes on day 8 of culture. The model has achieved $R^{2}=0.74$ and RMSE $=0.067$ estimated on the whole set and $R^{2} \mathrm{cv}=$ 0.45 and $\mathrm{RMSE}_{\mathrm{Cv}}=0.094$ obtained by cross-validation. (B) Plot of observed compared with predicted estimated specific production rate (pg/cell/h) using the PLS model. (C and D) Contribution of individual targets to principal components on day 4 (C) and 8 (D) of culture. (E and F) Heat map of correlation analysis between pairs of target gene mRNA on day 4 (E) and 8 (F). Red blocks are highly correlated, blue blocks have low correlation. Correlation coefficients are given for pairs of target genes where the correlation is statistically significant $(P \leqslant 0.05)$. (G and $\mathbf{H})$ PCA scores plot of principal component 1 (PC1) compared with principal component 2 (PC2) of mRNA data on day 4 (G) and 8 (H). Individual data points are coloured according to hierarchical cluster analysis and cell line identity given for outliers and small clusters. 
Table 3 Hierarchical cluster analysis of cell lines

Cell lines were clustered using mRNA and protein expression levels of target genes.

\begin{tabular}{|c|c|c|c|c|c|}
\hline & & Cell lines in cluster & $\begin{array}{l}\text { Mean product } \\
\text { concentration (mg/l) }\end{array}$ & Mean IVC (106 cells/ml.h) & $\begin{array}{l}\text { Mean estimated specific } \\
\text { production rate }(\mathrm{pg} / \mathrm{ml} / \mathrm{h})\end{array}$ \\
\hline \multirow[t]{6}{*}{ Day 4 mRNA } & 1 & 77 & 357 & 1182 & 0.3021 \\
\hline & 2 & $\begin{array}{l}2,24,25,35,38,40,41,42,46,48,56 \\
\quad 71,76,97,106,114,121,124,127 \\
\quad 137,142,146,149,164\end{array}$ & $346 \pm 140$ & $1173 \pm 207$ & $0.2997 \pm 0.1202$ \\
\hline & 3 & 75 & 609 & 1162 & 0.5236 \\
\hline & 4 & 150 & 392 & 1303 & 0.3008 \\
\hline & 5 & 33,34 & 205 & 1447 & 0.1384 \\
\hline & 6 & 52 & 22 & 686 & 0.0320 \\
\hline \multirow[t]{6}{*}{ Day 8 mRNA } & 1 & 150 & 392 & 1303 & 0.3008 \\
\hline & 2 & $\begin{array}{l}2,24,25,33,34,35,38,40,41,42,46 \\
\quad 48,56,77,97,106,114,121,124 \\
\quad 127,137,146,149,164\end{array}$ & $326 \pm 125$ & $1200 \pm 215$ & $0.2771 \pm 0.1076$ \\
\hline & 3 & 142 & 162 & 1287 & 0.1259 \\
\hline & 4 & 52 & 22 & 686 & 0.0320 \\
\hline & 5 & 76 & 395 & 936 & 0.4215 \\
\hline & 6 & 75,71 & 650 & 1183 & 0.5488 \\
\hline \multirow[t]{7}{*}{ Day 4 protein } & 1 & $33,38,40,46$ & $329 \pm 180$ & $1256 \pm 170$ & $0.2745 \pm 0.1632$ \\
\hline & 2 & $\begin{array}{l}2,24,34,35,41,106,114,127,137 \\
\quad 142,146,149,150,164\end{array}$ & $302 \pm 138$ & $1192 \pm 249$ & $0.2549 \pm 0.1058$ \\
\hline & 3 & 121 & 350 & 1165 & 0.3000 \\
\hline & 4 & $25,42,48,71,97,124$ & $403 \pm 160$ & $1192+163$ & $0.3477 \pm 0.1510$ \\
\hline & 5 & 52,77 & 189 & $934-$ & 0.1671 \\
\hline & 6 & 75 & 609 & 1162 & 0.5236 \\
\hline & 7 & 56 & 415 & 1395 & 0.2971 \\
\hline \multirow[t]{6}{*}{ Day 8 protein } & 1 & 150 & 392 & 1303 & 0.3008 \\
\hline & 2 & $\begin{array}{l}2,24,25,33,34,35,38,40,41,42,46 \\
\quad 48,52,77,97,106,114,121,124 \\
127,137,142,164\end{array}$ & $300 \pm 129$ & $1164 \pm 237$ & $0.2597 \pm 0.1156$ \\
\hline & 3 & 71,56 & 553 & 1299 & 0.4356 \\
\hline & 4 & 149 & 563 & 1332 & 0.4228 \\
\hline & 5 & 146 & 146 & 1271 & 0.1149 \\
\hline & 6 & 75 & 609 & 1162 & 0.5236 \\
\hline
\end{tabular}

their intracellular amount of eIFs. On both day 4 and 8, two clusters were identified and four singletons (Figures $3 \mathrm{G}$ and $3 \mathrm{H}$ ). Table 3 describes cluster membership and specific production rate changes within clusters. On day 4 of culture, cell lines 33 and 34 cluster together and away from the main cluster and outliers. There are only two cell lines within the cluster, therefore statistical testing cannot be applied; however, cell line 34 has the highest IVC of any of the cell lines and cell line 33 ranks six out of 30 cell lines for IVC. Each of these cell lines individually rank in the top four highest for four out of eight of the amounts of target gene mRNA on day 4 (cell line 33 for eIF3b, eIF3c, eIF3h and PAIP and cell line 34 for eIF3a, eIF3c, eIF4G and PAIP), which no other cell line achieves. However, by day 8 neither cell line ranks in the top 3 for any of the target mRNAs and these cell lines rank twenty-ninth and nineteenth for specific production rate respectively.

On day 8 , the two cell lines that rank highest according to both product yield and estimated qP (cell lines 71 and 75) belong to a separate cluster. These two cell lines stand out in terms of their amounts of intracellular eIF-encoding mRNA; on day 8, they rank in the top five for mRNA expression levels of all target genes apart from eIF3a where cell line 71 but not 75 is ranked in the top five. This clustering suggests that although individually not all of the target genes may have a statistically-significant correlation with specific production rate, higher amounts of the entire target gene mRNAs is correlated with good production cell lines. The stoichiometric requirement of eIFs in the initiation complex would require all eIFs to be in high abundance for translation initiation to be enhanced. These data suggest that, on day 8 , rather than the amount of any individual eIF-encoding mRNA being limiting, there is a general requirement for sufficient amounts of mRNA of all of the target genes.

\section{Analysis of target translation initiation factor protein levels}

Western blot analysis of the target eIF proteins (Figures 1B and 2) was performed relative to the housekeeping gene $\beta$ actin. There are six isoforms of eIF4G1 $(\mathrm{a}-\mathrm{f})$ ranging from $155 \mathrm{kDa}$ (a) to $175 \mathrm{kDa}$ (f) $[35,36]$. Only the longest isoform is distinguishable from the shorter isoforms on the blots in the present study and, therefore, data were collected for the long isoform eIF4G1a (termed eIF4GL here) and grouped short isoforms eIF4G1b-f (termed eIF4GS here). During apoptosis, eIF4G1 is a specific target for cleavage by caspase-3 and initial cleavage events generate fragments at 120 and $150 \mathrm{kDa}$ respectively. Final cleavage products termed N-FAG (fragment (of eIF4G)) (81-110 kDa), M-FAG (76 kDa) and C-FAG (50 kDa) arise later [37]. The total amount of cleavage product was also analysed (termed eIF4GC here) alongside total eIF4G (eIF4GT = eIF4GL + eIF4GS + eIF4GC). There are also two isoforms of PAIP1 (46 kDa PAIPS and $54 \mathrm{kDa}$ PAIPL), which were analysed individually and as a total.

Initially, linear regression was applied to the Western blot data using the same methodology as described for the mRNA data. Notably, there were more target proteins associated with IVC on day 4 than there were on day 8 (Table 2; Supplementary Figure 
S1), consistent with the qRT-PCR data. However, those proteins that were significantly associated with IVC, were different targets to those that were significant at the mRNA level but still were negatively associated with IVC (Table 2). Interestingly, eIF4G1 cleavage products were negatively correlated with IVC, suggesting that if there is any loss of fidelity of eIF4G1, then cells are unable to grow as fast as those where eIF4G1 is intact. PAIP1 levels were also strongly negatively correlated with IVC at this time point. There were no negative correlations with any of the target genes on either day with final product concentration or specific production rate. On day 4 , the intact isoforms of eIF4G1 positively correlated with final product; however, for specific production rate, this correlation only held true for the long isoform of eIF4G1 and the long isoform of PAIP1. On day eight eIF4GL, eIF4GS and eIF4GT along with PABP1 positively correlated with both final product concentration and specific production rate. We were not able to build successful models of the Western blot data using the PLS algorithm and, therefore, PCA was applied to this data (Figures 4A-4D). On day 4 and day 8, two components described $99.5 \%$ and $99.4 \%$ of the variance in the data respectively. On each day, variance in eIF4G1 data contributed the most to principal component 1 and variance in PAIP1 contributed the most to principal component 2 .

Correlations between the amount of mRNA encoding target proteins gives some information as to those genes responding to the cellular environment. Correlated protein levels provide additional information as to the stoichiometry at which proteins are functional, although we have not considered post-translational modifications and the role these may play in this analysis. The analysis is complicated at the protein level by the fact that a number of the target genes' activity is controlled by posttranslational modifications and that some may have a function outside of the translation initiation complex. However, on day 4 of culture, when cells are actively growing and dividing, the most highly correlated proteins were PABP1 and PAIP1 (Figures 4E and $4 \mathrm{~F}$ ), which have previously been shown to have a $1: 1$ stoichiometry within the closed loop structure [38]. On day 8 , the second highest correlation is between eIF4G1 and PABP, which also interact directly to aid formation of the closed loop structure [39]. There are other statistically significant correlations as well, of note eIF3h and eIF3b on day 4 and eIF3a with eIF4G1 on day 8. We note that across this panel of 30 cell lines, the mRNA level of target genes did not directly correlate with the protein level for any of the genes investigated (see section below). Furthermore, when looking at target levels on day 4 compared with day 8 , the only target for which there was a statistically significant correlation $(P \leqslant 0.05)$ was eIF3h and this was true for both protein and mRNA expression.

Cluster analysis of cell lines by target protein levels (Figures 4C and 4D; Table 3 ) on day 4 did not reveal any clusters with specific desirable traits (high IVC or high productivity), with the exception of cell line 75, which ranked second highest by final product concentration and estimated relative production rate and is an outlier from the other cell lines. On day 8 of the culture, the three top cell lines by product concentration in the harvest medium are outliers or in the case of cell line 71 in a two cell-line cluster with cell line 56, which itself was a top three cell line when taken to the bioreactor in the original cell line studies $[2,3]$.

\section{mRNA and protein dual analysis}

No statistically significant correlations were identified between corresponding factors in the Western blot data and qPCR data taken on day 4 or day 8 , except for eIF3h. In the case of
eIF3h, correlation analysis revealed that the amount of eIF3h mRNA on day 4 correlated to amounts on day 8 (correlation coefficient $0.71, P \leqslant 0.05$ ), with the same holding true for the amount of eIF3h protein (correlation coefficient $0.50, P \leqslant 0.05$ ). No correlations for these parameters were found for the other target genes. Identifying cell lines that cluster away from the main group using protein and mRNA cluster analysis on day 8 resulted in identification of the top two performing cell lines (71 and 75) and one mid-table cell line (150), with cell line 75 being an outlier in all four sub-data sets.

\section{DISCUSSION}

In the present study we have investigated the relationship between translation initiation factor mRNA and protein amounts and industrially desirable phenotypes, high IVC and $\mathrm{qP}$, in $\mathrm{CHO}$ cells using a panel of mAb producing cells lines as a model system. Our studies show that across a large panel of cell lines of markedly differing productivities that high producing cell lines have finely-tuned translational machinery in a delicate balance correlated with productivity and IVC (Figure 5). mRNA level and translation efficiency have previously been shown to be uncoupled for $95 \%$ of $\mathrm{CHO}$ genes investigated in a correlation analysis of transcriptome and translatome data [31], an observation that holds true for the eight translation initiation target genes investigated in the present study. This uncoupling of mRNA and protein expression levels can in part be attributed to miRNA-mediated translational repression of a given mRNA upon imperfect base pairing in the $3^{\prime}-$ UTR [40]. Although in many cases miRNAmediated repression ultimately leads to mRNA decay, it has also been shown that such repression can occur without decay and can be reversible [41-43]. Translational control at the level of elongation has also recently been shown to be a key determinant that affects polypeptide amounts, a lack of control of this regulatory step leading to tumorigenesis [44] and playing a role in neurodegeneration [45]. Furthermore, numerous posttranslational modifications fine tune protein expression levels at any given time in the cell, impacting on half-life, decay and localization [46].

Recent evidence suggests the control of initiation factor expression levels is more complex than currently appreciated, with eIF3i identified from a SILAC (stable isotope labeling by amino acids in cell culture) panel of $>3000$ proteins as the protein with the least divergent protein expression levels in an evolutionary context, although its mRNA levels are not nearly so tightly controlled [47]. Despite this, the level of some of the target gene mRNAs did have a relationship with key performance indicators in the present study: on day 4 primarily with growth related characteristic (IVC) and on day 8 with product concentration related characteristics. This is perhaps not surprising as at day 4 the cells are in rapid exponential growth phase, whereas at day 8 the cells are in stationary growth phase and peak $\mathrm{mAb}$ production ( $\mathrm{g} / \mathrm{l} / \mathrm{d})$ is known to occur during this phase of culture [3].

It was striking that the quantities of eIF3h mRNAs consistently show a negative correlation with the desirable parameters (IVC and $\mathrm{qP}$ ) on both day 4 and 8 , although the corresponding protein did not. eIF3h and PABP1 belong to a group of mRNAs with a $5^{\prime}$-terminal oligopyrimidine tract (5'-TOPs) $[48,49]$, with PABP1 being a well characterized member of this family. The $5^{\prime}$-TOP motif is predominantly associated with mRNAs that encode proteins with a role in ribosome biogenesis, such as mRNAs for ribosomal proteins [50]. 5'-TOP mRNAs are candidates for growth-dependent translational control and are tightly regulated during times of nutrient deprivation $[51,52]$. On day 4 , when eIF3h 
A

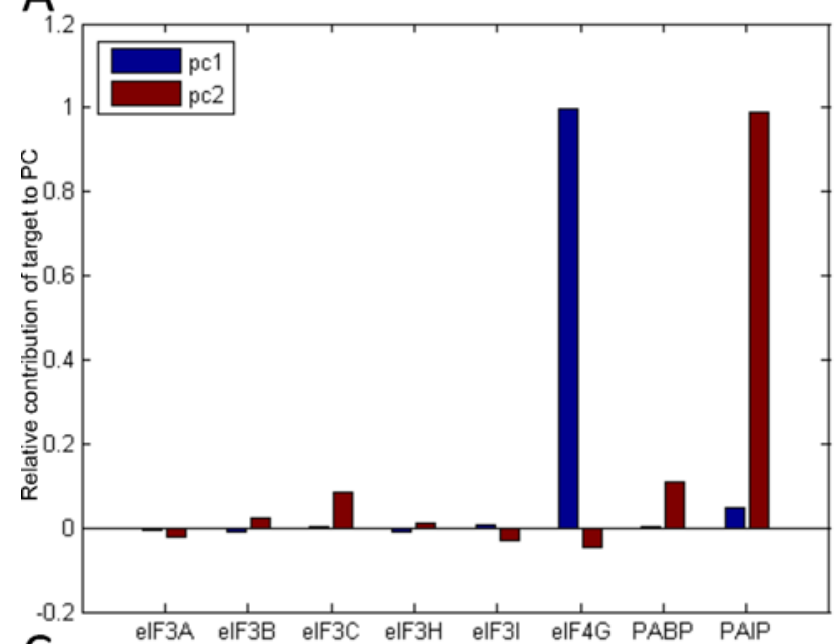

$\mathrm{C}_{10}$

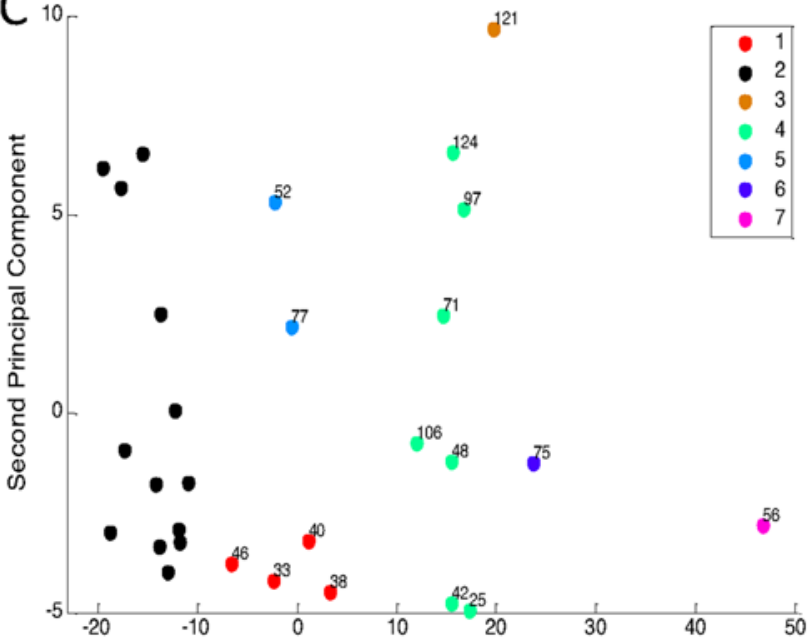

E

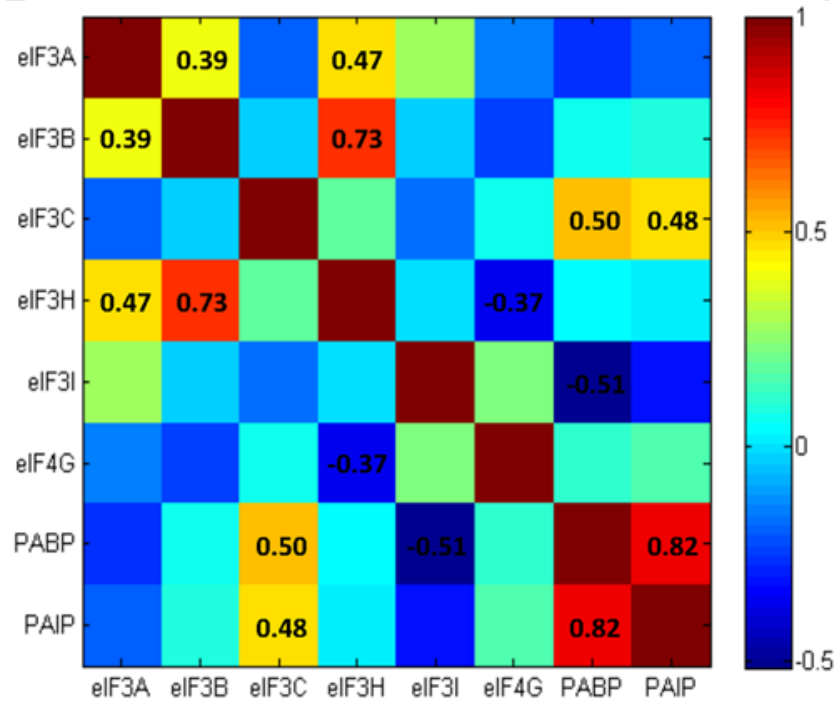

B

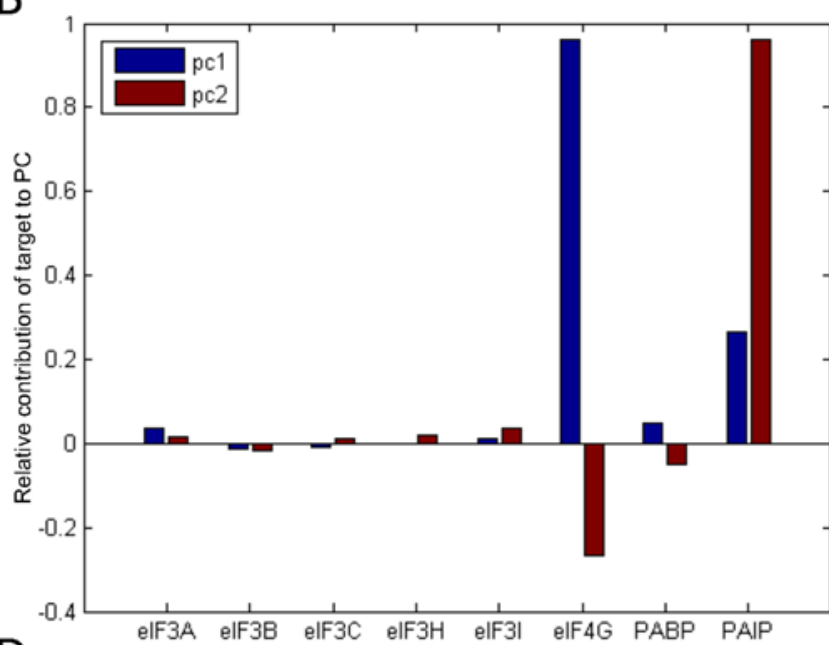

$D_{25}$

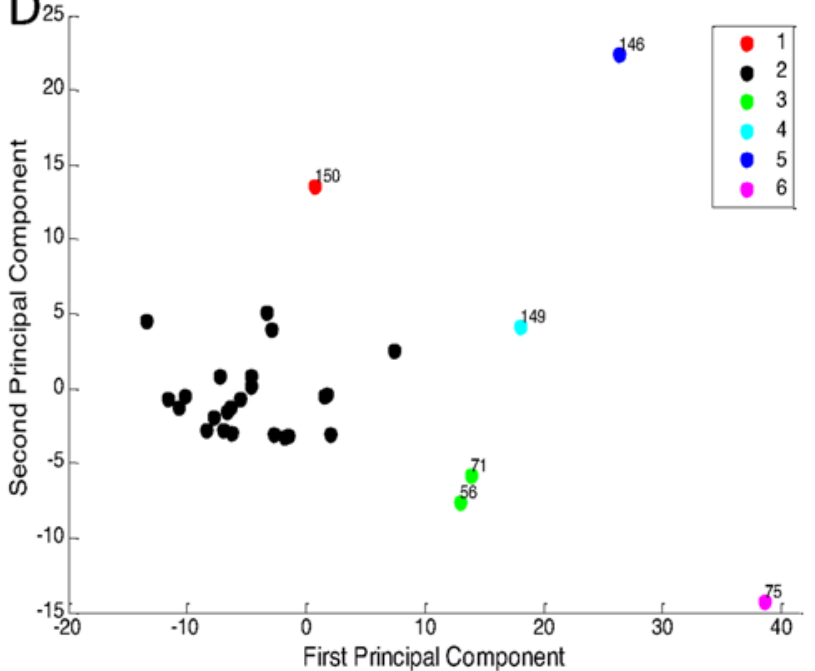

$\mathrm{F}$

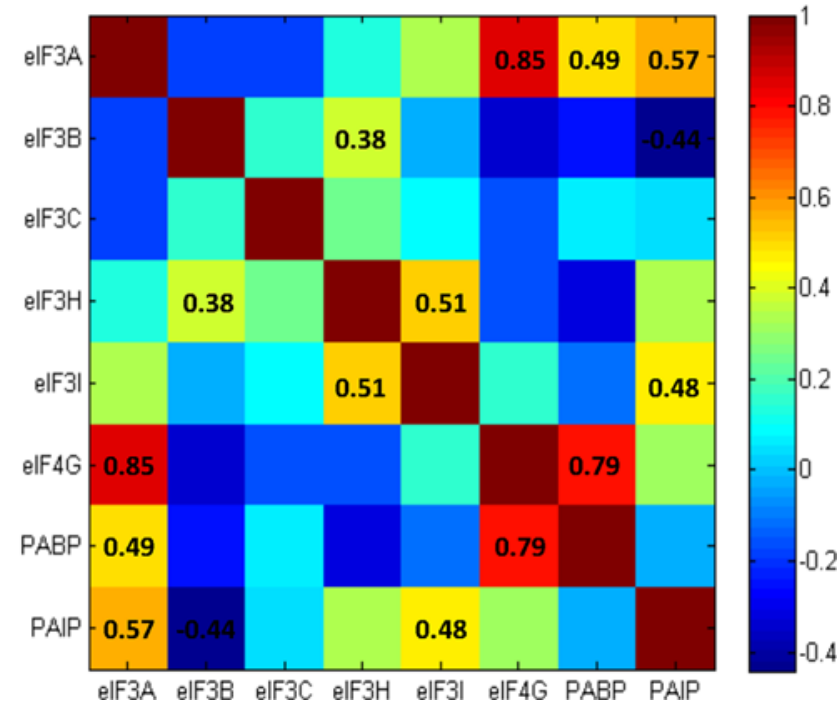

Figure 4 Principle component and cluster analysis of target gene protein levels

(A and B) Contribution of individual targets to principal components on day 4 (A) and 8 (B) of the culture. (C and $\mathbf{D})$ PCA scores plot of PC1 compared with PC2 of protein data on day 4 (C) and 8 (D). Individual data points are coloured according to hierarchical cluster analysis and cell line identity given for outliers and small clusters. (E and $\mathbf{F}$ ) Heat map of correlation analysis between pairs of target gene protein levels on day $4(\mathbf{E})$ and $8(\mathbf{F})$. Red blocks are highly correlated, light blue blocks have low correlation, dark blue blocks have negative correlation. Correlation coefficients are given for pairs of target genes where the correlation is statistically significant $(P \leqslant 0.05)$. 

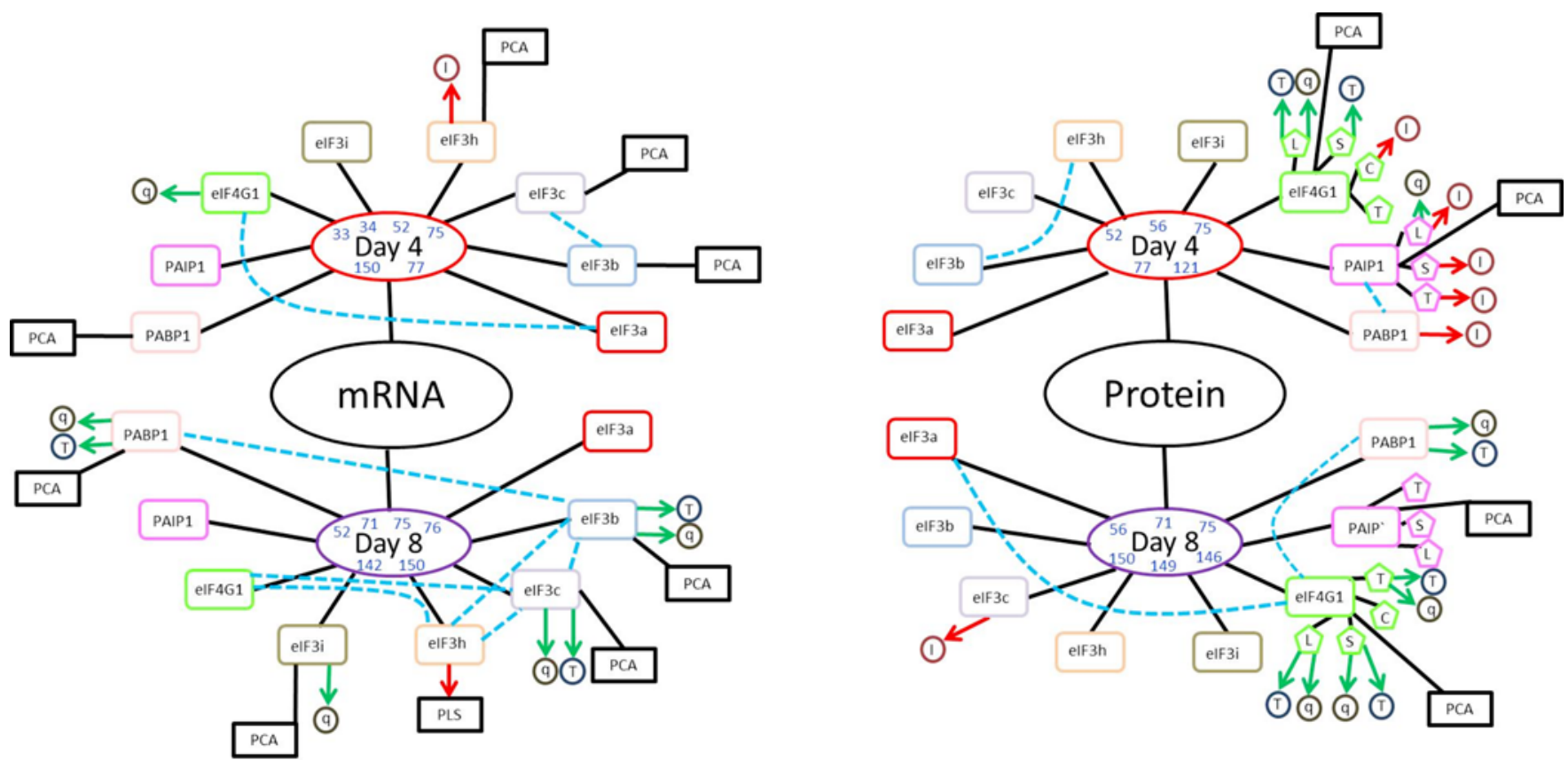

Figure 5 Summary of statistical analyses

Schematic diagram representing statistically significant findings from each of the four data sets: (red arrow) statistically significant $(P \leqslant 0.05)$ negative association from linear regression, unless otherwise indicated, (green arrow) statistically significant $(P \leqslant 0.05)$ positive association from linear regression unless otherwise indicated, (blue broken line) statistically significant correlation $(P \leqslant 0.05)$ of target levels. Only strong associations where $r \geqslant 0.6$ are identified in this schematic. (I) Integral of viable cell concentration IVC, (T) final product titre, (q) estimated specific production rate, $(\mathrm{L})$ long isoform, $(\mathrm{S})$ short isoform, $(\mathrm{T})$ total protein, $(\mathrm{C})$ cleavage products. Where a number is given in blue, it denotes cell line number of those cell lines identified as outliers by hierarchical cluster analysis. Black boxes highlight targets identified by PLS analysis or PCA. A number of factors were identified to contribute to four principle components by PCA analysis of mRNA data. For clarity, only the two targets contributing most significantly to the first and second principal components are identified in this summary diagram.

mRNA levels negatively correlate with IVC related parameters, PABP1 mRNA expression levels do not show a significant correlation with any of the parameters; however, at this time point PABP1 mRNA is the only mRNA other than eIF3h where the regression coefficient with IVC is negative. Translation of TOP mRNAs has been shown to have an eIF4E-BP mediated hyper-dependence on mTOR and unlike other mRNAs require eIF4G1 to anchor eIF4E to the cap for translation initiation [49]. Overexpression of mTOR in a model mAb producing cell line enhanced several characteristics relevant to $\mathrm{mAb}$ production, including cell proliferation and specific productivity [53]. The mechanisms by which mTOR overexpression influences such key performance indicators are expected to be numerous and complex but at least in part attributable to the influence the mTOR pathway has on ribosomal protein expression via the translation of 5'-TOP mRNAs [53,54]. Additionally, upon amino acid starvation, the 5 -TOP mRNAs are liberated from the polysomal fraction and are re-localized in stress granules [55]. It has been shown in yeast that the discrepancy between protein and transcript levels of highly abundant transcripts is partly attributable to the sequestration of abundant transcripts into storage granules, such as SG (stress granules) and P-bodies (cytoplasmic processing bodies) [56] and that this sequestration enhances cell viability. The true mechanism by which $5^{\prime}$-TOP mRNAs are regulated remains elusive, but in the panel of cell lines here where abundance of target mRNAs with 5'TOP motifs is negatively correlated to key performance indicators we speculate that poor producing cell lines are unable to respond to nutrient deprivation and growth limitations in the same way as high producing cell lines, resulting in a dysregulation of 5'-TOP mRNA levels.

The present study focused on investigating translation initiation factors within the closed loop complex. In a previous study that determined global absolute protein copy numbers in exponentially growing mouse NIH3T3 cells, including for the eight targets of the present study, eIF4G1 had significantly lower copy numbers than any of the other seven target proteins and third lowest of the 43 initiation factors detected, with only eIF4G3 and eIF4H having lower copy numbers [57]. We found that at the protein level total expression of intact eIF4G1 strongly positively correlates with desirable cell parameters, with cleaved eIF4G1 strongly negatively correlating. Low copy numbers of eIF4G1 in the cell indicate it would be a limiting factor in the formation of the closed loop structure and, therefore, our data suggest that cell lines with higher eIF4G1 levels are able to better initiate translation and exhibit increased productivity. Additionally, the dependence of 5'TOP mRNAs on eIF4G1 to anchor eIF4E to the cap for efficient translation would mean that those cells with increased eIF4G1 are better able to translate such mRNAs and hence synthesize the target proteins required for the translational machinery. PAIP1 was also identified by PCA analysis as being the second most important target protein of those investigated in the present study and, in the NIH3T3 copy number analysis [57], this was the second least abundant of the targets investigated, again suggesting PAIP1 may be limiting in the formation of the closed loop structure.

Within the initiation factor eIF3 complex all 13 subunits are at unit stoichiometry with three stable complexes [eIF3(c:d:e:l:k), eIF3(f:h:m) and eIF3(a:b:i:g)]. Interactions between eIF3b:c and eIF3c:h link these stable subunits [34]. With the exception of day 8 mRNA, correlation analysis revealed few strong correlations between target eIF3 gene expression levels; however, at the mRNA level, eIF3b:c were strongly correlated at both time points, indicating a co-regulation of these crucial eIF3 subunits at the mRNA level. Additionally, at the mRNA level these two targets had the highest positive relationship with performance indicators, 
adding further weight to the importance of forming this essential part of the eIF3 scaffold complex [58] on the outcome of cell growth and productivity.

We used a number of statistical approaches (Figure 5) to ask different questions of our data set and, in particular, to determine if any of the target genes could be used in a screening approach to identify high-producing cell lines. On day 8, mRNA levels of a number of the factors strongly correlated with one another as well as quantities of factors correlating with key cell growth/productivity parameters, indicating that stationary phase would be a good point at which to assay mRNA for the purpose of predicting the phenotype of a cell line (e.g. high IVC and/or productivity). The PLS model at this time point is predictive and could be used to identify cell lines for development or those to discard as likely to be poor growers or poor producers of the target recombinant protein. It was not unexpected that protein amounts did not strongly correlate with one another due to the known role of a number of the factors outside of their stoichiometric role in translation initiation [59]. Regression and PCA analysis do however identify that the amount of intact eIF4G1 protein is a strong indicator of both final product concentration and estimated specific production rate on both days 4 and 8 of the culture.

In summary, we have shown that factors involved in closed loop formation of the translation initiation complex in mammalian cells exist in a delicately controlled balance in industrial cell lines with a high mAb yield. Our analyses suggest that determining the relative amounts of a number of these factors could be exploited as a screening tool to identify cell lines capable of high IVC and productivity phenotypes. We suggest that applying such a screen to identify new host cell lines with the ability to maintain this complex or by using synthetic biology cell engineering approaches to maintain the levels of these proteins, could be applied to generate new host cell lines with high IVC and recombinant protein productivity attributes.

\section{AUTHOR CONTRIBUTION}

Mark Smales conceived the project design. Emma Mead participated in performing and analysing all experiments. Mark Smales, Emma Mead, Marc Feary, Robert Young and Lin Zhang all contributed to experimental design. Rosalyn Masterton participated in performing Western blots. Olga Obrezanova and Emma Mead performed statistical analysis. Emma Mead and Mark Smales wrote the paper and all authors contributed to subsequent preparation of the paper and have approved the paper.

\section{ACKNOWLEDGEMENTS}

We are grateful to Lonza Slough Process Analytics for titre measurements and Dr Andy Racher (Lonza Biologics) for critical evaluation of the manuscript.

\section{FUNDING}

This work was supported by the Lonza Biologics and the Pfizer.

\section{REFERENCES}

1 Schaub, J., Clemens, C., Schorn, P., Hildebrandt, T., Rust, W., Mennerich, D., Kaufmann, H. and Schulz, T.W. (2010) $\mathrm{CHO}$ gene expression profiling in biopharmaceutical process analysis and design. Biotechnol. Bioeng. 105, 431-438 CrossRef PubMed

2 Porter, A.J., Racher, A.J., Preziosi, R. and Dickson, A.J. Strategies for selecting recombinant $\mathrm{CHO}$ cell lines for CGMP manufacturing: improving the efficiency of cell line generation. Biotechnol. Prog. 26, 1455-1464 CrossRef PubMed
3 Porter, A.J., Dickson, A.J. and Racher, A.J. (2010) Strategies for selecting recombinant $\mathrm{CHO}$ cell lines for cGMP manufacturing: realizing the potential in bioreactors. Biotechnol. Prog. 26, 1446-1454 CrossRef PubMed

4 Povey, J.F., O'Malley, C.J., Root, T., Martin, E.B., Montague, G.A., Feary, M., Trim, C., Lang, D.A., Alldread, R. and Racher, A.J. (2014) Rapid high-throughput characterisation, classification and selection of recombinant mammalian cell line phenotypes using intact cell MALDI-ToF mass spectrometry fingerprinting and PLS-DA modelling. J. Biotechnol. 184, 84-93 CrossRef PubMed

5 Mead, E.J., Chiverton, L.M., Spurgeon, S.K., Martin, E.B., Montague, G.A., Smales, C.M. and von der Haar, T. (2012) Experimental and in silico modelling analyses of the gene expression pathway for recombinant antibody and by-product production in NSO cell lines. PLoS One 7, e47422 CrossRef PubMed

6 Rita Costa, A., Elisa Rodrigues, M., Henriques, M., Azeredo, J. and Oliveira, R. (2010) Guidelines to cell engineering for monoclonal antibody production. Eur. J. Pharm. Biopharm. 74, 127-138 CrossRef PubMed

7 McLeod, J., O'Callaghan, P.M., Pybus, L.P., Wilkinson, S.J., Root, T., Racher, A.J. and James, D.C. (2011) Biotechnol. Bioeng 108, 2193-2204 CrossRef

8 O'Callaghan, P.M., McLeod, J., Pybus, L.P., Lovelady, C.S., Wilkinson, S.J., Racher, A.J., Porter, A. and James, D.C. (2010) Cell line-specific control of recombinant monoclonal antibody production by $\mathrm{CHO}$ cells. Biotechnol. Bioeng. 106, 938-951 CrossRef PubMed

9 Mead, E.J., Chiverton, L.M., Smales, C.M. and von der Haar, T. (2009) Identification of the limitations on recombinant gene expression in $\mathrm{CHO}$ cell lines with varying luciferase production rates. Biotechnol. Bioeng. 102, 1593-1602 CrossRef PubMed

10 Hershey, J.W. (2010) Regulation of protein synthesis and the role of elF3 in cancer. Braz. J. Med. Biol. Res. 43, 920-930 CrossRef PubMed

11 Mead, E.J. and Smales, C.M. (2011) mRNA Translation and recombinant gene expression from mammalian cell expression systems. In Comprehensive Biotechnology (Moo-Young, M., ed.), 2nd edn, pp. 403-409, Academic Press, Burlington CrossRef

12 LeFebvre, A.K., Korneeva, N.L., Trutschl, M., Cvek, U., Duzan, R.D., Bradley, C.A., Hershey, J.W. and Rhoads, R.E. (2006) Translation initiation factor elF4G-1 binds to elF3 through the elF3e subunit. J. Biol. Chem. 281, 22917-22932 CrossRef PubMed

13 Zhang, L., Pan, X. and Hershey, J.W. (2007) Individual overexpression of five subunits of human translation initiation factor elF3 promotes malignant transformation of immortal fibroblast cells. J. Biol. Chem. 282, 5790-5800 CrossRef PubMed

14 Roobol, A., Carden, M.J., Newsam, R.J. and Smales, C.M. (2009) Biochemical insights into the mechanisms central to the response of mammalian cells to cold stress and subsequent rewarming. FEBS. J. 276, 286-302 CrossRef PubMed

15 Kaufmann, H., Mazur, X., Fussenegger, M. and Bailey, J.E. (1999) Influence of low temperature on productivity, proteome and protein phosphorylation of $\mathrm{CHO}$ cells. Biotechnol. Bioeng. 63, 573-582 CrossRef PubMed

16 Wells, S.E., Hillner, P.E., Vale, R.D. and Sachs, A.B. (1998) Circularization of mRNA by eukaryotic translation initiation factors. Mol. Cell 2, 135-140 CrossRef PubMed

17 Martineau, Y., Derry, M.C., Wang, X., Yanagiya, A., Berlanga, J.J., Shyu, A.-B.B., Imataka, H., Gehring, K. and Sonenberg, N. (2008) Poly(A)-binding protein-interacting protein 1 binds to eukaryotic translation initiation factor 3 to stimulate translation. Mol. Cell. Biol. 28, 6658-6667 CrossRef PubMed

18 Jackson, R.J., Hellen, C.U. and Pestova, T.V. (2010) The mechanism of eukaryotic translation initiation and principles of its regulation. Nat. Rev. Mol. Cell. Biol. 11, 113-127 CrossRef PubMed

19 Margaliot, M. and Tuller, T. (2013) Ribosome flow model with positive feedback. J. R. Soc. Interface. 10, 20130267 CrossRef PubMed

20 Underhill, M.F., Birch, J.R., Smales, C.M. and Naylor, L.H. (2005) elF2alpha phosphorylation, stress perception, and the shutdown of global protein synthesis in cultured $\mathrm{CHO}$ cells. Biotechnol. Bioeng. 89, 805-814 CrossRef PubMed

21 Chong, W.P., Sim, L.C., Wong, K.T. and Yap, M.G. (2009) Enhanced IFNgamma production in adenosine-treated $\mathrm{CHO}$ cells: a mechanistic study. Biotechnol. Prog. 25 , 866-873 CrossRef PubMed

22 Smales, C.M., Dinnis, D.M., Stansfield, S.H., Alete, D., Sage, E.A., Birch, J.R., Racher, A.J., Marshall, C.T. and James, D.C. (2004) Comparative proteomic analysis of GS-NSO murine myeloma cell lines with varying recombinant monoclonal antibody production rate. Biotechnol. Bioeng. 88, 474-488 CrossRef PubMed

23 Stansfield, S.H., Allen, E.E., Dinnis, D.M., Racher, A.J., Birch, J.R. and James, D.C. (2007) Dynamic analysis of GS-NSO cells producing a recombinant monoclonal antibody during fed-batch culture. Biotechnol. Bioeng. 97, 410-424 CrossRef PubMed

24 Bahr, S.M., Borgschulte, T., Kayser, K.J. and Lin, N. (2009) Using microarray technology to select housekeeping genes in Chinese hamster ovary cells. Biotechnol. Bioeng. 104, 1041-1046 CrossRef $\underline{\text { PubMed }}$

25 Vandesompele, J., De Preter, K., Pattyn, F., Poppe, B., Van Roy, N., De Paepe, A. and Speleman, F. (2002) Accurate normalization of real-time quantitative RT-PCR data by geometric averaging of multiple internal control genes. Genome. Biol. 3, RESEARCH0034 CrossRef 
26 Bradford, M.M. (1976) A rapid and sensitive method for the quantitation of microgram quantities of protein utilizing the principle of protein-dye binding. Anal. Biochem. 72 , 248-254 CrossRef PubMed

27 Laemmli, U.K. (1970) Cleavage of structural proteins during the assembly of the head of bacteriophage T4. Nature 227, 680-685 CrossRef PubMed

28 Görlach, M., Burd, C.G. and Dreyfuss, G. (1994) The mRNA poly(A)-binding protein: Iocalization, abundance, and RNA-binding specificity. Exp. Cell. Res. 211, 400-407 CrossRef PubMed

29 Wold, H. (1975) Soft modeling by latent variables; the nonlinear iterative partial least squares approach. In Perspectives in Probability and Statistics: Papers in Honour of M. S. Bartlett on the Occasion of his Sixty-Fifth Birthday (Gani, J., ed.), pp. 117-138, Academic Press, Burlington

30 Geladi, P. and Kowalski, B.R. (1986) Partial least-squares regression - a tutorial. Anal. Chim. Acta 185, 1-17 CrossRef

31 Courtes, F.C., Lin, J., Lim, H.L., Ng, S.W., Wong, N.S.C., Koh, G., Vardy, L., Yap, M.G.S., Lo0, B. and Lee, D.-Y.Y. (2013) Translatome analysis of CHO cells to identify key growth genes. J Biotechnol 167, 215-224 CrossRef PubMed

32 Brewer, J.W. and Hendershot, L.M. (2005) Building an antibody factory: a job for the unfolded protein response. Nat. Immunol. 6, 23-29 CrossRef PubMed

33 Masutani, M., Sonenberg, N., Yokoyama, S. and Imataka, H. (2007) Reconstitution reveals the functional core of mammalian elF3. EMBO J. 26, 3373-3383 CrossRef PubMed

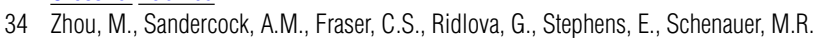
Yokoi-Fong, T., Barsky, D., Leary, J.A., Hershey, J.W. et al. (2008) Mass spectrometry reveals modularity and a complete subunit interaction map of the eukaryotic translation factor elF3. Proc. Natl. Acad. Sci. U.S.A. 105, 18139-18144 CrossRef PubMed

35 Morley, S.J., Coldwell, M.J. and Clemens, M.J. (2005) Initiation factor modifications in the preapoptotic phase. Cell. Death. Differ. 12, 571-584 CrossRef PubMed

36 Coldwell, M.J. and Morley, S.J. (2006) Specific isoforms of translation initiation factor 4GI show differences in translational activity. Mol. Cell. Biol. 26, 8448-8460 CrossRef PubMed

37 Marissen, W.E. and Lloyd, R.E. (1998) Eukaryotic translation initiation factor 4G is targeted for proteolytic cleavage by caspase 3 during inhibition of translation in apoptotic cells. Mol. Cell. Biol. 18, 7565-7574 CrossRef PubMed

38 Roy, G., De Crescenzo, G., Khaleghpour, K., Kahvejian, A., O'Connor-McCourt, M. and Sonenberg, N. (2002) Paip1 interacts with poly(A) binding protein through two independent binding motifs. Mol. Cell. Biol. 22, 3769-3782 CrossRef PubMed

39 Park, E.-H., Walker, S.E., Lee, J.M., Rothenburg, S., Lorsch, J.R. and Hinnebusch, A.G. (2011) Multiple elements in the elF4G1 N-terminus promote assembly of elF4G1•PABP mRNPs in vivo. EMBO J. 30, 302-316 CrossRef PubMed

40 Wilczynska, A. and Bushell, M. (2014) The complexity of miRNA-mediated repression. Cell Death Differ. 22, 22-33 CrossRef PubMed

41 Béthune, J., Artus-Revel, C.G. and Filipowicz, W. (2012) Kinetic analysis reveals successive steps leading to miRNA-mediated silencing in mammalian cells. EMBO. Rep. 13, 716-723 CrossRef PubMed

42 Bhattacharyya, S.N., Habermacher, R., Martine, U., Closs, E.I. and Filipowicz, W. (2006) Relief of microRNA-mediated translational repression in human cells subjected to stress. Cell 125, 1111-1124 CrossRef PubMed

Received 21 August 2015/28 September 2015; accepted 29 September 2015

Accepted Manuscript online 29 September 2015, doi:10.1042/BJ20150928
43 Djuranovic, S., Nahvi, A. and Green, R. (2012) miRNA-mediated gene silencing by translational repression followed by mRNA deadenylation and decay. Science $\mathbf{3 3 6}$ 237-240 CrossRef PubMed

44 Faller, W.J., Jackson, T.J., Knight, J.R.P., Ridgway, R.A., Jamieson, T., Karim, S.A., Jones, C., Radulescu, S., Huels, D.J. and Myant, K.B. (2015) mTORC1-mediated translational elongation limits intestinal tumour initiation and growth. Nature $\mathbf{5 1 7}, 497-500$ CrossRef PubMed

45 Peretti, D., Bastide, A., Radford, H., Verity, N., Molloy, C., Martin, M.G., Moreno, J.A., Steinert, J.R., Smith, T. and Dinsdale, D. (2015) RBM3 mediates structural plasticity and protective effects of cooling in neurodegeneration. Nature $\mathbf{5 1 8}, 236-239$ CrossRef PubMed

46 Choudhary, C. and Mann, M. (2010) Decoding signalling networks by mass spectrometry-based proteomics. Nat. Rev. Mol. Cell. Biol. 11, 427-439 CrossRef PubMed

47 Khan, Z., Ford, M.J., Cusanovich, D.a., Mitrano, A., Pritchard, J.K. and Gilad, Y. (2013) Primate transcript and protein expression levels evolve under compensatory selection pressures. Science 342, 1100-1104 CrossRef PubMed

48 ladevaia, V., Caldarola, S., Tino, E., Amaldi, F. and Loreni, F. (2008) All translation elongation factors and the $\mathrm{e}, \mathrm{f}$, and $\mathrm{h}$ subunits of translation initiation factor 3 are encoded by 5'-terminal oligopyrimidine (TOP) mRNAs. RNA 14, 1730-1736 CrossRef PubMed

49 Thoreen, C.C., Chantranupong, L., Keys, H.R., Wang, T., Gray, N.S. and Sabatini, D.M. (2012) A unifying model for mTORC1-mediated regulation of mRNA translation. Nature 485, 109-113 CrossRef PubMed

50 Levy, S., Avni, D., Hariharan, N., Perry, R.P. and Meyuhas, 0. (1991) Oligopyrimidine tract at the 5 ' end of mammalian ribosomal protein mRNAs is required for their translational control. Proc. Natl. Acad. Sci. U.S.A. 88, 3319-3323 CrossRef PubMed

51 Meyuhas, 0. (2000) Synthesis of the translational apparatus is regulated at the translational level. Eur. J. Biochem. 267, 6321-6330 CrossRef PubMed

52 Ivanov, P., Kedersha, N. and Anderson, P. (2011) Stress puts TIA on TOP. Genes Dev. 25, 2119-2124 CrossRef PubMed

53 Dreesen, I.A.J. and Fussenegger, M. (2011) Ectopic expression of human mTOR increases viability, robustness, cell size, proliferation, and antibody production of Chinese hamster ovary cells. Biotechnol. Bioeng. 108, 853-866 CrossRef PubMed

54 Mahajan, P.B. (1994) Modulation of transcription of rRNA genes by rapamycin. Int. J. Immunopharmacol. 16, 711-721 CrossRef PubMed

55 Damgaard, C.K. and Lykke-Andersen, J. (2011) Translational coregulation of 5'TOP mRNAs by TIA-1 and TIAR. Genes Dev. 25, 2057-2068 CrossRef PubMed

56 Lavut, A. and Raveh, D. (2012) Sequestration of highly expressed mRNAs in cytoplasmic granules, P-bodies, and stress granules enhances cell viability. PLoS Genet. 8, e1002527 CrossRef PubMed

57 Schwanhäusser, B., Busse, D., Li, N., Dittmar, G., Schuchhardt, J., Wolf, J., Chen, W. and Selbach, M. (2011) Global quantification of mammalian gene expression control. Nature 473, 337-342 CrossRef PubMed

58 Hinnebusch, A.G. (2006) elF3: a versatile scaffold for translation initiation complexes. Trends Biochem. Sci. 31, 553-562 CrossRef PubMed

59 Sha, Z., Brill, L.M., Cabrera, R., Kleifeld, O., Scheliga, J.S., Glickman, M.H., Chang, E.C and Wolf, D.A. (2009) The elF3 interactome reveals the translasome, a supercomplex linking protein synthesis and degradation machineries. Mol. Cell 36, 141-152 CrossRef PubMed 